\title{
Prevalence of low back pain and associated risk factors amongst adult patients presenting to a Nigerian family practice clinic, a hospital-based study
}

\author{
Authors: \\ Adetola M. Ogunbode \\ Lawrence A. Adebusoye ${ }^{1}$ \\ Temitope O. Alonge ${ }^{2}$ \\ Affiliations: \\ ${ }^{1}$ Family Medicine \\ Department, University \\ College Hospital, Ibadan, \\ Nigeria \\ ${ }^{2}$ Department of Orthopaedics \\ and Trauma, University \\ College Hospital,Ibadan, \\ Nigeria \\ Correspondence to: \\ Adetola Ogunbode \\ Email: \\ tolaogunbode@yahoo.co.uk \\ Postal address: \\ University College Hospital \\ PMB 5116, Agodi, Ibadan, \\ Nigeria

\section{Dates:} \\ Received: 12 Mar. 2012 \\ Accepted: 15 Oct. 2012 \\ Published: 15 May 2013 \\ How to cite this article: \\ Ogunbode AM, Adebusoye \\ LA, Alonge TO. Prevalence of \\ low back pain and associated \\ risk factors amongst adult \\ patients presenting to a \\ Nigerian family practice \\ clinic, a hospital-based \\ study. Afr J Prm Health Care \\ Fam Med. 2013;5(1), Art.\# \\ 441,8 pages. http://dx.doi. \\ org/10.4102/phcfm.v5i1.441

\section{Copyright:} \\ C 2013. The Authors. \\ Licensee: AOSIS \\ OpenJournals. This work \\ is licensed under the \\ Creative Commons \\ Attribution License.

Background: Low back pain (LBP) is a common health problem with concomitant disability which has assumed a public health importance in our setting.

Objectives: The aim of this study was to determine the prevalence of LBP and associated risk factors amongst adult patients attending the General Outpatients' Clinic of the University College Hospital in Ibadan, Nigeria.

Method: This was a cross-sectional study of 485 respondents. A semi-structured questionnaire was used to obtain information on socio-demography, lifestyle, occupation and other risk factors associated with LBP.

Results: There were 288 (59.4\%) female and 197 (40.6\%) male respondents. The point prevalence of LBP was $46.8 \%$. Occupational activities, previous back injury and tobacco smoking were significant associated factors for the total population. For the female respondents, logistic regression analysis showed that a waist circumference of $88 \mathrm{~cm}$ or more, dysmenorrhea, previous back injury and being engaged in an occupation were the most significant factors associated with LBP. However, previous back injury was the most significant factor associated with LBP for the male respondents.

Conclusion: The prevalence of LBP amongst adult patients in our setting is high, with preventable and treatable predisposing factors. Public health efforts should be directed at educating people on occupational activities and lifestyle habits.

Prévalence des lombalgies et facteurs de risque associés chez les patients adultes se présentant dans un centre médical familial du Nigeria, étude en milieu hospitalier

Contexte: La lombalgie est un problème de santé courant, associé à un handicap, ce problème étant important sur le plan de la santé publique dans notre contexte.

Objectifs: L'objectif de cette étude était de déterminer la prévalence des lombalgies et des facteurs de risque associés chez les patients adultes se présentant au centre de consultation externe de l'hôpital universitaire d'Ibadan, au Nigeria.

Méthode: Il s'agit d'une étude transversale réalisée auprès de 485 personnes interrogées. Un questionnaire semi-structuré a été utilisé afin d'obtenir des informations sur les facteurs sociodémographiques, le style de vie, la profession ainsi que d'autres facteurs de risque associés à la lombalgie.

Résultats: Le groupe de personnes interrogées se composait de $288(59,4 \%)$ femmes et de 197 (40,6\%) hommes. La prévalence ponctuelle des lombalgies était de 46,8\%. Les activités professionnelles, des blessures dorsales antérieures et la consommation de tabac étaient des facteurs associés significatifs pour la population totale. Pour les femmes interrogées, l'analyse de régression logistique a montré qu'un tour de taille de $88 \mathrm{~cm}$ ou plus, une dysménorrhée, des blessures dorsales antérieures et l'activité professionnelle étaient les facteurs associés à la lombalgie les plus significatifs. Chez les hommes interrogés, les blessures dorsales antérieures constituaient le facteur le plus important associé à la lombalgie.

Conclusion: La prévalence de la lombalgie chez les patients adultes est élevée dans notre contexte, les facteurs de prédisposition pouvant faire l'objet d'une prévention et d'un traitement. Les efforts de santé publique devraient s'attacher à éduquer la population sur les activités professionnelles et les habitudes de vie.

\section{Introduction}

Musculoskeletal problems are prevalent amongst the adult population. ${ }^{1}$ Globally, chronic low back pain (LBP) is a common health problem. ${ }^{2}$ People with chronic LBP experience huge social, mental, physical and occupational disruptions. ${ }^{3}$ The mental impact of LBP include anxiety, depression 
and sleeplessness, whilst poor physical performance and deterioration in health status are the physical impacts. ${ }^{1}$ LBP results in an inability to carry out social activities and it decreases the capability to perform occupational activities since it mostly affects adults of working age. ${ }^{1,4}$ Disability caused by LBP stems from the pain and/or loss of function inflicted on the sufferers. Chronic LBP is one of the four disabilities causing musculoskeletal conditions - the others being osteoarthritis, osteoporosis and rheumatoid arthritis. ${ }^{5}$ The economic burden of LBP on the society, especially in lowresourced continents like Africa, is enormous and continues to increase. Billions of dollars spent annually on managing LBP further constrains the fragile health care system in Africa, which is already ravaged by the HIV epidemic. ${ }^{5}$

About $40 \%$ of sick absences from work is because of LBP making it the second most common cause of workplace absenteeism after the common cold. ${ }^{6}$ Chronic LBP is the most common musculoskeletal problem encountered in the workplace, with attendant loss of quality of life and financial difficulty. ${ }^{7}$ Chronic LBP is prevalent in many industrialised societies with prevalence rates of $21 \%$ and $39 \%$ being reported in the general population - and even higher in the occupational setting. ${ }^{8}$ In the USA, LBP is the commonest musculoskeletal illness with $12 \%-30 \%$ of the population affected at any given time. ${ }^{9}$

Occupation-related factors are the most important risks associated with LBP. ${ }^{9}$ More than $80 \%$ of the population will experience an episode of LBP at some time during their lives. ${ }^{10}$ The clinical course is benign for most, with $95 \%$ of those afflicted recovering within a few months of onset. Some, however, will not recover and will develop chronic LBP, i.e. pain that lasts for three months or longer. ${ }^{10}$

Risk factors for developing LBP could be immutable (nonmodifiable) or mutable (modifiable). The immutable factors are age, parity, previous history of LBP and major scoliosis, whilst the mutable factors include a sedentary lifestyle, obesity, tobacco smoking and drug dependence. ${ }^{11}$ Other mutable factors are occupation-related: poor posturing, prolonged sitting, twisting, bending, stooping and lifting of heavy loads. ${ }^{11}$

There is scanty information available on LBP in resourceconstrained countries like Nigeria. ${ }^{7}$ This may be due to fact that LBP is perceived to be of little public health importance when compared with other medical conditions such as hypertension and diabetes mellitus. ${ }^{7}$ This study was carried out to determine the point prevalence and risk factors of LBP amongst adult patients presenting to a family practice clinic in Nigeria.

\section{Ethical consideration}

The head of the Family Medicine department (UCH, Ibadan) approved this study. Respondents gave their informed consent before the administration of their questionnaire and physical examination.

\section{Methods \\ Context of the study}

The study was conducted at the General Outpatients' (GOP) Clinic of the Family Medicine Department of the University College Hospital (UCH) in Ibadan, Nigeria. UCH is a tertiary institution founded in 1957 in the cosmopolitan city of Ibadan. Ibadan is the capital of the Oyo state in south-western Nigeria and has a population of 3.6 million people, mainly of the Yoruba tribe. ${ }^{12}$ Most patients coming to $\mathrm{UCH}$ are seen first at the GOP Clinic, which functions as a secondary care clinic within a tertiary hospital setting. Patients are at first contact seen by consultants and resident doctors in family medicine.

\section{Design}

This was a cross-sectional study.

\section{Study population}

The population consisted of 485 patients who presented to the GOP Clinic (UCH) between 15 January 2011 and 30 March 2011. The inclusion criteria were all patients aged 18 years and above who consented to take part in the study. Those who did not consent to the study, who had congenital deformity of the spine or who were too ill to participate in the study were excluded.

\section{Sampling technique}

All adult patients who met the study criteria were consecutively selected.

\section{Procedure}

A semi-structured questionnaire was used to interview the respondents. The questionnaire was pretested to determine if the questions were clear and comprehensive enough to address the set objectives of the study and necessary amendments were then made. Information obtained from the respondents included their socio-demographic characteristics and lifestyle habits. Additionally, their health care utilisation pattern was obtained by asking them about the number of times they had been hospitalised for LBP, the total period spent on admission, the frequency of outpatient hospital visits in the last year and the treatment they sought for their LBP. Anthropometric measurements of height, weight, waist and hip circumferences were carried out for all respondents.

The weight (in kilogram) was divided by the height (meter) and then squared to calculate the body mass index (BMI). The BMI was graded along the World Health Organization's (WHO) classification, where 'Underweight' refers to a BMI less than $18.5 \mathrm{~kg} / \mathrm{m}^{2}$, 'Normal' to a BMI of $18.5 \mathrm{~kg} /$ $\mathrm{m}^{2}-24.9 \mathrm{~kg} / \mathrm{m}^{2}$, 'Overweight' to a BMI of $25.0 \mathrm{~kg} / \mathrm{m}^{2}-$ $29.9 \mathrm{~kg} / \mathrm{m}^{2}$ and 'Obese' to a BMI greater than $30.0 \mathrm{~kg} / \mathrm{m}^{2}$. To identify individuals with possible health risks, the waist circumference of the respondents was measured and this 
was based on the threshold values of $\geq 88 \mathrm{~cm}$ for women and $\geq 102 \mathrm{~cm}$ for men. ${ }^{14}$ The waist/hip ratio (WHR) was calculated by dividing the waist circumference by the hip circumference. ${ }^{14}$ The cut-off point of WHR was defined as $\geq 0.85$ for women and $\geq 1.00$ for men. ${ }^{14}$ The questionnaire took an average of $22 \mathrm{~min}$ to be completed.

\section{Anthropometric measurements}

Height was recorded to the nearest $0.1 \mathrm{~m}$ with a measurement stand (stadiometre) that was positioned on a flat surface. The respondents were asked to remove their shoes and their heels were positioned against the wall, with their scapula, buttocks and heels resting against the wall. Female respondents were asked to remove their headwear. The weight of the respondents was measured to the nearest $0.1 \mathrm{~kg}$ using a standard weighing scale manufactured by Hana, China. Respondents stood on the weighing scale after removing their personal effects. The researcher made the readings whilst standing in front of the respondents and the zero mark was checked for accuracy after every reading. Waist and hip circumferences were measured to the nearest $0.1 \mathrm{~m}$ using a flexible non-elastic measuring tape.

\section{Follow-up}

Respondents were treated for their primary health complaints and those needing further treatment were referred to other specialty clinics within the facility.

\section{Analysis}

Administered questionnaires were checked, sorted and coded serially at the end of each study day. The data was entered, cleansed and analysed using SPSS $₫$ (version 16). Descriptive statistics was employed for the socio-demography, lifestyle and health care utilisation pattern of the respondents. Categorical and discrete variables were tested using the Chisquare statistics and continuous variables were tested using the $t$-test. The relationship between socio-demography, lifestyle, health care utilisation and LBP was explored using logistic regression analysis. The $p$-value of significance was set at $\leq 0.05$.

\section{Results}

There were 288 (59.4\%) female and 197 (40.6\%) male respondents in the study population, with the female to male ratio being 1.5 to 1 . The mean \pm standard deviation (SD) of the respondents' age was $42.5 \pm 15.5$ years (range: 18 to 85 years). Their monthly income ranged from 2000 to 400000 Naira (\$13.33 to \$2666.67) with a median income of 18500 Naira (\$123.33). The modal age group was less than 30 years and only 70 respondents $(14.4 \%)$ were elderly. The majority of the respondents were married and 306 (63.1\%) were literate, having completed the first 10 years of formal education (i.e. attained senior secondary and tertiary education). There were 331 respondents $(68.2 \%)$ living with their immediate family (spouse and children or grandchildren) and 363 (74.8\%) were currently engaged in occupational activities. The male respondents were mostly self-supporting whereas the females were mostly dependent on their spouses for financial support (Table 1). The self-reported point prevalence of LBP was $46.8 \%$ (Figure 1 ).

Table 2 shows the socio-demographic characteristics of the respondents by the prevalence of LBP. The point prevalence of LBP was higher amongst men compared with women $(50.3 \%$ vs. $44.4 \%)$, but without statistical significance $\left(\chi^{2}=\right.$ $1.586, p=0.208)$. The prevalence of LBP increased gradually with age: from $44.9 \%$ for respondents younger than 30 years to $55.6 \%$ for the age group 51 years - 60 years. However, a reduction in the prevalence of LBP was observed after the age of 60 (Figure 2). There was therefore no statistical association between the prevalence of LBP and age $\left(\chi^{2}=3.007, p=0.558\right)$. A higher prevalence of LBP was found in respondents who only had primary school education (55.7\%), lived alone $(50.6 \%)$, had more than five children $(52.3 \%)$ and were selfsupporting (49.6\%), as shown in Table 2. The prevalence of LBP was significantly higher amongst respondents who were currently engaged in occupational activities than those who were not $(49.9 \%$ vs. $37.7 \%)$, where $\chi^{2}=5.421$ and $p=0.020$ (Table 2). The majority (80\%) of the respondents in social class I had LBP. However, Table 2 shows that there was no significant association between social class and LBP $\left(\chi^{2}=\right.$ $4.185, p=0.382)$.

The highest proportion of LBP (63.6\%) was found amongst respondents who commonly adopted the stooping position during their daily activities, whilst the lowest proportion $(48.5 \%)$ was found in those who commonly adopted the standing position (Table 3). There was no significant association between commonly adopted posture and LBP $\left(\chi^{2}\right.$ $=2.174, p=0.704)$. The prevalence of LBP was significantly higher amongst respondents who had previous back injury (91.3\%) compared with those who did not (44.8\%), where $\chi^{2}=14.64$ and $p<0.001$. The lifestyle habits of the respondents showed that 71 respondents (14.6\%) regularly consumed alcohol, 12 respondents $(2.5 \%)$ smoked tobacco and 102 respondents $(21.0 \%)$ engaged in regular physical exercise. The prevalence of LBP was significantly higher in respondents who smoked tobacco than those who did not $(91.7 \%$ vs. $45.7 \%)$, where $\chi^{2}=9.946$ and $p=0.002$. However, no association was found between the prevalence of LBP and alcohol consumption or physical exercise. Mattress or foam $(94.8 \%)$ was the commonest sleeping material used by the respondents, with the majority $(83.7 \%)$ using the soft type. The majority of respondents using either the firm type (55.4\%) or the orthopedic type (70.0\%) had LBP. However, there was no significant association between the sleeping material and $\operatorname{LBP}\left(\chi^{2}=1.950, p=0.377\right)$. Amongst the female respondents, the prevalence of LBP was significantly higher in those who had dysmenorrhea compared with those who did not $(57.9 \%$ vs. $39.6 \%$ ), where $\chi^{2}=7.565$ and $p=0.006$ (Table 3).

Anthropometric measurements of the respondents showed that the mean weight of the respondents was $66.7 \mathrm{~kg} \pm$ $13.8 \mathrm{~kg}(37 \mathrm{~kg}-129 \mathrm{~kg})$ and the mean height was $1.63 \mathrm{~m} \pm$ $0.09 \mathrm{~m}$ (range: $1.10 \mathrm{~m}-1.90 \mathrm{~m}$ ). The mean body mass index 
TABLE 1: Socio-demographic characteristics of the respondent

\begin{tabular}{|c|c|c|c|c|c|c|c|}
\hline \multirow[t]{2}{*}{ Variables } & \multirow[t]{2}{*}{ Characteristics } & \multicolumn{2}{|c|}{ Female } & \multicolumn{2}{|c|}{ Male } & \multicolumn{2}{|c|}{ Total } \\
\hline & & $n=\mathbf{2 8 8}$ & $\%$ & $n=197$ & $\%$ & $N=485$ & $\%$ \\
\hline \multirow[t]{5}{*}{ Age group (years) } & $\leq 30$ & 86 & 62.3 & 52 & 37.7 & 138 & 100.0 \\
\hline & $31-40$ & 74 & 64.9 & 40 & 35.1 & 114 & 100.0 \\
\hline & $41-50$ & 58 & 58.0 & 42 & 42.0 & 100 & 100.0 \\
\hline & $51-60$ & 38 & 60.3 & 25 & 39.7 & 63 & 100.0 \\
\hline & $>60$ & 29 & 41.4 & 41 & 58.6 & 70 & 100.0 \\
\hline \multirow[t]{4}{*}{ Marital status } & Single & 54 & 47.8 & 59 & 52.2 & 113 & 100.0 \\
\hline & Married & 196 & 59.4 & 134 & 40.6 & 330 & 100.0 \\
\hline & Separated and/or divorced & 7 & 77.8 & 2 & 22.2 & 9 & 100.0 \\
\hline & Widowed & 31 & 93.9 & 2 & 6.1 & 33 & 100.0 \\
\hline \multirow[t]{4}{*}{ Educational level attained } & No education & 42 & 62.7 & 25 & 37.3 & 67 & 100.0 \\
\hline & Primary school & 55 & 62.5 & 33 & 37.5 & 88 & 100.0 \\
\hline & Junior secondary school & 14 & 58.3 & 10 & 41.7 & 24 & 100.0 \\
\hline & Senior secondary school & 53 & 47.7 & 58 & 52.3 & 111 & 100.0 \\
\hline \multirow[t]{5}{*}{ Living arrangement } & Alone & 26 & 32.9 & 53 & 67.1 & 79 & 100.0 \\
\hline & Spouse & 167 & 60.5 & 109 & 39.5 & 276 & 100.0 \\
\hline & Children and/or grandchildren & 46 & 83.6 & 9 & 16.4 & 55 & 100.0 \\
\hline & Relations & 47 & 69.1 & 21 & 30.9 & 68 & 100.0 \\
\hline & Friends & 2 & 28.6 & 5 & 71.4 & 7 & 100.0 \\
\hline \multirow[t]{4}{*}{ Number of children } & $1-2$ & 81 & 54.0 & 69 & 46.0 & 150 & 100.0 \\
\hline & $3-4$ & 57 & 60.6 & 37 & 39.4 & 94 & 100.0 \\
\hline & $\geq 5$ & 86 & 65.2 & 46 & 34.8 & 132 & 100.0 \\
\hline & $1-2$ & 64 & 58.7 & 45 & 41.3 & 109 & 100.0 \\
\hline \multirow[t]{5}{*}{ Financial support } & Self & 99 & 42.7 & 133 & 57.3 & 232 & 100.0 \\
\hline & Spouse & 110 & 87.3 & 16 & 12.7 & 126 & 100.0 \\
\hline & Parent & 44 & 60.3 & 29 & 39.7 & 73 & 100.0 \\
\hline & Children and/or grandchildren & 27 & 64.3 & 15 & 35.7 & 42 & 100.0 \\
\hline & Friends and other relatives & 8 & 69.2 & 4 & 30.8 & 12 & 100.0 \\
\hline \multirow[t]{5}{*}{ Social class } & 1 & 1 & 20.0 & 4 & 80.0 & 5 & 100.0 \\
\hline & II & 8 & 57.1 & 6 & 42.9 & 14 & 100.0 \\
\hline & III & 53 & 52.0 & 49 & 48.0 & 102 & 100.0 \\
\hline & IV & 16 & 64.0 & 9 & 36.0 & 25 & 100.0 \\
\hline & $\mathrm{V}$ & 210 & 61.9 & 129 & 38.1 & 339 & 100.0 \\
\hline
\end{tabular}

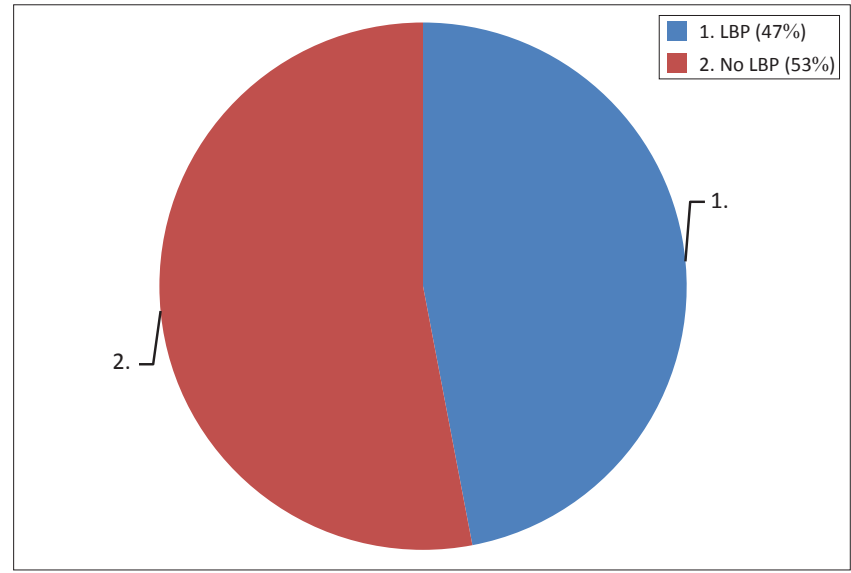

LBP, Lower back pain.

FIGURE 1: Point prevalence of low back pain.

(BMI) was $25.2 \mathrm{~kg} / \mathrm{m}^{2} \pm 5.5 \mathrm{~kg} / \mathrm{m}^{2}\left(16.2 \mathrm{~kg} / \mathrm{m}^{2}-51.9 \mathrm{~kg} / \mathrm{m}^{2}\right)$. The mean weight of male respondents $(67.3 \mathrm{~kg} \pm 1.3 \mathrm{~kg})$ was more than those of the females $(66.4 \mathrm{~kg} \pm 1.4 \mathrm{~kg})$ without a significant difference $(t=0.539, p=0.463)$. The mean height of the male respondents was significantly higher than those of their female counterparts $(1.67 \mathrm{~m} \pm 0.09 \mathrm{~m}$ vs. $1.60 \mathrm{~m} \pm 0.08 \mathrm{~m})$, where $t=83.340$ and $p<0.0001$. Conversely, the mean BMI of the female respondents was significantly higher than those of their male counterparts $(25.91 \pm 5.52$ vs. $24.16 \pm 5.29)$, where $t=11.758$ and $p=0.001$. The mean waist circumference of the respondents was $79.2 \mathrm{~cm} \pm 12.9 \mathrm{~cm}(50 \mathrm{~cm}-128 \mathrm{~cm})$ and the mean hip circumference was $87.2 \mathrm{~cm} \pm 15.4 \mathrm{~cm}(43 \mathrm{~cm}-$ $133.1 \mathrm{~cm}$ ). The mean waist/hip ratio (WHR) was $0.91 \pm 0.07$ $(0.48-1.36)$. The mean waist and hip circumference of the female respondents was significantly higher than those of their male counterparts $(81.11 \pm 13.79$ vs. $76.37 \pm 10.89$, where $t=16.001$ and $p<0.0001$, and $89.82 \pm 16.10$ vs. $83.29 \pm 13.45$, where $t=21.473, p<0.0001)$ respectively. However, the mean WHR of the females was significantly lower than those of the males $(0.908 \pm 0.07$ vs. $0.923 \pm 0.08)$, where $t=5.267$ and $p=$ 0.022 (Table 4 ).

Table 5 depicts the physical characteristics of the respondents by the prevalence of LBP. The majority of the respondents (45.2\%) had a normal BMI, whilst $46.8 \%$ were either overweight or obese. The highest proportion of LBP $(48.6 \%)$ was found in those who were overweight, but there was no significant association between LBP and BMI $\left(\chi^{2}=\right.$ $0.739, p=0.864)$. A higher proportion of men $(70 \%)$ with a 
TABLE 2: Socio-demographic characteristics of the respondents by the prevalence of low back pain.

\begin{tabular}{|c|c|c|c|c|c|c|c|c|c|c|}
\hline \multirow[t]{2}{*}{ Variables } & \multirow[t]{2}{*}{ Characteristics } & \multicolumn{2}{|c|}{ LBP } & \multicolumn{2}{|c|}{ No LBP } & \multicolumn{2}{|c|}{ Total } & \multirow[t]{2}{*}{$\overline{\chi^{2}}$} & \multirow[t]{2}{*}{$d f$} & \multirow[t]{2}{*}{$p$} \\
\hline & & $n=227$ & $\%$ & $n=258$ & $\%$ & $N=485$ & $\%$ & & & \\
\hline \multirow[t]{5}{*}{ Age group (years) } & $\leq 30$ & 62 & 44.9 & 76 & 55.1 & 138 & 100.0 & 3.007 & 4 & 0.557 \\
\hline & $31-40$ & 53 & 46.5 & 61 & 53.5 & 114 & 100.0 & & & \\
\hline & $41-50$ & 48 & 48.0 & 52 & 52.0 & 100 & 100.0 & & & \\
\hline & $51-60$ & 35 & 55.6 & 28 & 44.4 & 63 & 100.0 & & & \\
\hline & $>60$ & 29 & 41.4 & 41 & 58.6 & 70 & 100.0 & & & \\
\hline \multirow[t]{2}{*}{ Sex } & Female & 128 & 44.4 & 160 & 55.6 & 288 & 100.0 & 1.586 & 1 & 0.208 \\
\hline & Male & 99 & 50.3 & 98 & 49.7 & 197 & 100.0 & & & \\
\hline \multirow[t]{4}{*}{ Marital status } & Single & 56 & 49.6 & 57 & 50.4 & 113 & 100.0 & 5.756 & 3 & 0.124 \\
\hline & Married & 157 & 47.6 & 173 & 52.4 & 330 & 100.0 & & & \\
\hline & Separated and/or divorced & 5 & 55.6 & 4 & 44.4 & 9 & 100.0 & & & \\
\hline & Widowed & 9 & 27.3 & 24 & 72.7 & 33 & 100.0 & & & \\
\hline \multirow[t]{4}{*}{ Educational level attained } & No education & 28 & 41.8 & 39 & 58.2 & 67 & 100.0 & 3.724 & 4 & 0.445 \\
\hline & Primary school & 49 & 55.7 & 39 & 44.3 & 88 & 100.0 & & & \\
\hline & Senior secondary school & 51 & 45.9 & 60 & 54.1 & 111 & 100.0 & & & \\
\hline & Tertiary & 88 & 45.1 & 107 & 54.9 & 195 & 100.0 & & & \\
\hline \multirow[t]{5}{*}{ Living arrangement } & Alone & 40 & 50.6 & 39 & 49.4 & 79 & 100.0 & 1.060 & 4 & 0.901 \\
\hline & Spouse & 129 & 46.7 & 147 & 53.3 & 276 & 100.0 & & & \\
\hline & Children and/or Grandchildren & 23 & 41.8 & 32 & 58.2 & 55 & 100.0 & & & \\
\hline & Relations & 32 & 47.1 & 36 & 52.9 & 68 & 100.0 & & & \\
\hline & Friends & 3 & 42.9 & 4 & 57.1 & 7 & 100.0 & & & \\
\hline \multirow[t]{4}{*}{ Number of children } & None & 71 & 47.3 & 79 & 52.7 & 150 & 100.0 & 2.202 & 3 & 0.532 \\
\hline & $01-02$ & 42 & 44.7 & 52 & 55.3 & 94 & 100.0 & & & \\
\hline & $03-04$ & 57 & 43.2 & 75 & 56.8 & 132 & 100.0 & & & \\
\hline & $\geq 5$ & 57 & 52.3 & 52 & 47.7 & 109 & 100.0 & & & \\
\hline \multirow[t]{4}{*}{ Financial support } & Self & 115 & 49.6 & 117 & 50.4 & 232 & 100.0 & 2.605 & 4 & 0.626 \\
\hline & Spouse & 60 & 47.6 & 66 & 52.4 & 126 & 100.0 & & & \\
\hline & Parent & 29 & 39.7 & 44 & 60.3 & 73 & 100.0 & & & \\
\hline & Children and/or grandchildren & 18 & 42.9 & 24 & 57.1 & 42 & 100.0 & & & \\
\hline \multirow[t]{2}{*}{ Occupational status } & Presently engaged in an occupation & 181 & 49.9 & 182 & 50.1 & 363 & 100.0 & 5.421 & 1 & $0.020+$ \\
\hline & Not engaged in an occupation & 46 & 37.7 & 76 & 62.3 & 122 & 100.0 & & & \\
\hline \multirow[t]{5}{*}{ Social class } & 1 & 4 & 80.0 & 1 & 20.0 & 5 & 100.0 & 4.185 & 4 & 0.382 \\
\hline & $\|$ & 4 & 28.6 & 10 & 71.4 & 14 & 100.0 & & & \\
\hline & III & 48 & 47.1 & 54 & 52.9 & 102 & 100.0 & & & \\
\hline & IV & 11 & 44.0 & 14 & 56.0 & 25 & 100.0 & & & \\
\hline & V & 160 & 47.2 & 179 & 52.8 & 339 & 100.0 & & & \\
\hline
\end{tabular}

LBP, Low back pain

$\dagger$, Significant at $5 \%$ level of significance.

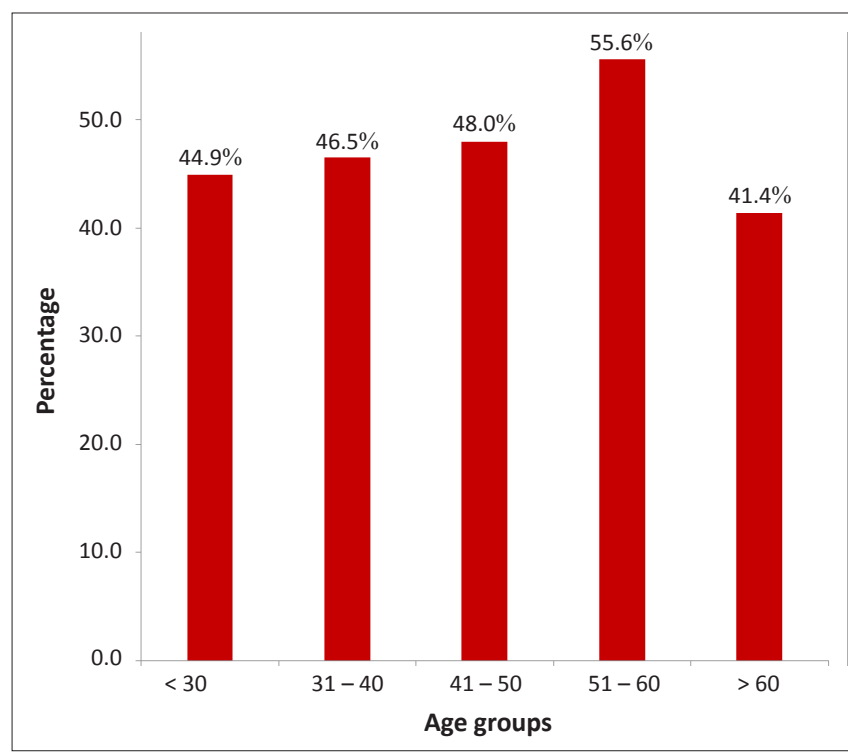

FIGURE 2: Prevalence of low back pain by age group. waist circumference of $102 \mathrm{~cm}$ or more reported LBP than those with a waist circumference less than $102 \mathrm{~cm}(49.2 \%)$. However, this difference was not statistically significant $\left(\chi^{2}=\right.$ $1.643, p=0.200)$. Amongst the females, the prevalence of LBP was significantly higher in those with a waist circumference of $88 \mathrm{~cm}$ or more than in those whose waist circumference was less than $88 \mathrm{~cm}(61.8 \%$ vs. $38.2 \%)$, where $\chi^{2}=12.656$ and $p<0.001$. Additionally, women with a WHR of 0.85 or more had a higher prevalence for LBP than those with a WHR less than $0.85(44.8 \%$ vs. $42.6 \%)$, where $\chi^{2}=0.081$ and $p=0.775$.

Of the 227 respondents who had LBP, only a few (22.5\%) reported experiencing their first episode of LBP. The average duration of the LBP was 24 months and 6 respondents (2.6\%) had been admitted to hospital for LBP. The average duration of hospitalisation was 3 days. Sixty-three respondents (27.8\%) with LBP reported visiting the hospital on an outpatient basis $2.1 \pm 1.8$ times in the last year. Of these 63 respondents, 26 $(41.3 \%)$ visited the hospital on an outpatient basis once, 27 
TABLE 3: Lifestyle habits of the respondents by the prevalence of low back pain.

\begin{tabular}{|c|c|c|c|c|c|c|c|c|c|c|}
\hline \multirow[t]{2}{*}{ Habits } & \multirow[t]{2}{*}{ Characteristics } & \multicolumn{2}{|c|}{ LBP } & \multicolumn{2}{|c|}{ No LBP } & \multicolumn{2}{|c|}{ Total } & \multirow[t]{2}{*}{$\chi^{2}$} & \multirow[t]{2}{*}{$d f$} & \multirow[t]{2}{*}{$p$} \\
\hline & & $n=227$ & $\%$ & $n=\mathbf{2 5 8}$ & $\%$ & $N=485$ & $\%$ & & & \\
\hline \multirow{4}{*}{$\begin{array}{l}\text { Posture mostly adopted during } \\
\text { daily activities }\end{array}$} & Standing & 94 & 48.5 & 100 & 51.5 & 194 & 100 & 2.174 & 4 & 0.704 \\
\hline & Sitting & 68 & 50.7 & 66 & 49.3 & 134 & 100 & & & \\
\hline & Stooping & 7 & 63.6 & 4 & 36.4 & 11 & 100 & & & \\
\hline & Squatting & 4 & 57.1 & 3 & 42.9 & 7 & 100 & & & \\
\hline \multirow[t]{2}{*}{ Previous back injury } & Yes & 21 & 91.3 & 4 & 8.7 & 25 & 100 & 14.647 & 1 & $0.001 \dagger$ \\
\hline & No & 206 & 44.8 & 254 & 55.2 & 460 & 100 & & & \\
\hline Alcohol & No & 197 & 47.6 & 217 & 52.4 & 414 & 100 & & & \\
\hline \multirow[t]{2}{*}{ Tobacco } & Yes & 11 & 91.7 & 1 & 8.3 & 12 & 100 & 9.946 & 1 & $0.002 \uparrow$ \\
\hline & No & 216 & 45.7 & 257 & 54.3 & 473 & 100 & & & \\
\hline \multirow[t]{2}{*}{ Regular physical exercise } & Yes & 49 & 48 & 53 & 52 & 102 & 100 & 0.079 & 1 & 0.779 \\
\hline & No & 178 & 46.5 & 205 & 53.5 & 383 & 100 & & & \\
\hline \multirow[t]{2}{*}{ Sleeping material } & Mattress/foam & 213 & 46.3 & 247 & 53.7 & 460 & 100 & 1.950 & 2 & 0.377 \\
\hline & Bare floor & 6 & 46.2 & 7 & 53.8 & 13 & 100 & & & \\
\hline \multirow[t]{3}{*}{ Type of mattress } & Soft & 170 & 44.2 & 215 & 55.8 & 385 & 100 & 5.129 & 2 & $=0.077$ \\
\hline & Firm & 36 & 55.4 & 29 & 44.5 & 65 & 100 & & & \\
\hline & Orthopaedic & 7 & 70 & 3 & 30 & 10 & 100 & & & \\
\hline
\end{tabular}

LBP, Low back pain.

$\dagger$, Significant at $5 \%$ level of significance.

\$. Type of mattress did not add up to 485 because it was a subset of sleeping material.

TABLE 4: Physical characteristics of the respondents by the prevalence of low back pain.

\begin{tabular}{|c|c|c|c|c|c|c|c|c|c|c|c|}
\hline \multirow[t]{2}{*}{ Characteristics } & \multirow[t]{2}{*}{ Gender } & \multirow[t]{2}{*}{ Sub-characteristics } & \multicolumn{2}{|c|}{ LBP } & \multicolumn{2}{|c|}{ No LBP } & \multicolumn{2}{|c|}{ Total } & \multirow[t]{2}{*}{$\chi^{2}$} & \multirow[t]{2}{*}{$d f$} & \multirow[t]{2}{*}{$\bar{p}$} \\
\hline & & & $n=227$ & $\%$ & $n=258$ & $\%$ & $N=485$ & $\%$ & & & \\
\hline \multirow[t]{4}{*}{ BMI } & - & Underweight & 16 & 41.0 & 23 & 59.0 & 39 & 100.0 & 0.739 & 3 & 0.864 \\
\hline & - & Normal & 103 & 47.0 & 116 & 53.0 & 219 & 100.0 & & & \\
\hline & - & Overweight & 69 & 48.6 & 73 & 51.4 & 142 & 100.0 & & & \\
\hline & - & Obese & 39 & 45.9 & 46 & 54.1 & 85 & 100.0 & & & \\
\hline \multirow[t]{3}{*}{ Waist circumference $(\mathrm{cm})$} & Males & $<102$ & 92 & 49.2 & 95 & 50.8 & 187 & 100.0 & 1.643 & 1 & 0.200 \\
\hline & & $\geq 102$ & 7 & 70.0 & 3 & 30.0 & 10 & 100.0 & & & \\
\hline & & $\geq 88$ & 47 & 61.8 & 29 & 38.2 & 76 & 100.0 & & & \\
\hline \multirow[t]{4}{*}{ Waist/hip ratio } & Males & $<1.00$ & 93 & 50.5 & 91 & 49.5 & 184 & 100.0 & 0.094 & 1 & 0.760 \\
\hline & & $\geq 1.00$ & 6 & 46.2 & 7 & 53.8 & 13 & 100.0 & & & \\
\hline & Females & $<0.85$ & 20 & 42.6 & 27 & 57.4 & 47 & 100.0 & 0.081 & 1 & 0.775 \\
\hline & & $\geq 0.85$ & 108 & 44.8 & 133 & 55.2 & 241 & 100.0 & & & \\
\hline
\end{tabular}

LBP, Low back pain; BMI, Body Mass Index.

$\dagger$, Significant at $5 \%$ level of significance.

TABLE 5: Logistic regression of significant risk factors and low back pain.

\begin{tabular}{|c|c|c|c|c|c|c|}
\hline \multirow[t]{2}{*}{ Variables } & \multirow[t]{2}{*}{ Characteristics } & \multirow[t]{2}{*}{$\beta$} & \multirow[t]{2}{*}{ Sig. } & \multirow[t]{2}{*}{ Odds Ratio $\operatorname{Exp}(\beta)$} & \multicolumn{2}{|c|}{ 95.0\% C.I. for $\operatorname{Exp}(\beta)$} \\
\hline & & & & & Lower & Upper \\
\hline \multirow[t]{6}{*}{ Females } & Waist circumference & 0.029 & $0.005 \dagger$ & 1.029 & 1.009 & 1.05 \\
\hline & Consumes tobacco & 21.538 & 1 & $2.26 \mathrm{E}+09$ & 0 & - \\
\hline & Dysmenorrhea & 0.816 & $0.012 \dagger$ & 2.26 & 1.197 & 4.268 \\
\hline & Previous back injury & 2.335 & $0.045 \dagger$ & 10.333 & 1.048 & 101.875 \\
\hline & Engaged in occupation & 0.87 & $0.011 \dagger$ & 2.388 & 1.219 & 4.676 \\
\hline & Constant & -44.911 & 1 & 0 & - & - \\
\hline \multirow[t]{6}{*}{ Males } & Consumes tobacco & -21.501 & 0.999 & 0 & 0 & - \\
\hline & Previous back injury & 2.871 & $0.006 \dagger$ & 17.662 & 2.256 & 138.265 \\
\hline & Engaged in occupation & 0.073 & 0.839 & 1.076 & 0.531 & 2.177 \\
\hline & Constant & 42.638 & 0.999 & $3.29 E+18$ & - & - \\
\hline & Engaged in occupation & 0.073 & 0.839 & 1.076 & 0.531 & 2.177 \\
\hline & Constant & 42.638 & 0.999 & $3.29 \mathrm{E}+18$ & - & - \\
\hline
\end{tabular}

$\dagger$, significant at $5 \%$ level of significance.

$(42.9 \%)$ visited twice, $5(7.9 \%)$ visited three times and $5(7.9 \%)$ visited four or more times in the last year.

Logistic regression tests were used separately for female and male respondents using all the variables that showed significant association with LBP. For the female respondents, waist circumference of $\geq 88 \mathrm{~cm}(p=0.005, \mathrm{OR}=1.029, \mathrm{CI}$ $=1.009-1.050)$, dysmenorrhea $(p=0.012, \mathrm{OR}=2.260, \mathrm{CI}=$ $1.197-4.268)$, previous back injury $(p=0.045, \mathrm{OR}=10.333$, $\mathrm{CI}=1.048-101.875)$ and being engaged in an occupation ( $p=0.011, \mathrm{OR}=2.388, \mathrm{CI}=1.219-4.676)$ were found to be most associated with LBP. Amongst the male respondents, 
previous back injury $(p=0.006, \mathrm{OR}=17.662, \mathrm{CI}=2.256-$ 138.265) was found to be most associated with LBP (Table 5).

\section{Discussion}

There is a global burden of LBP. The prevalence amongst Africans is also rising and it is a cause for concern. ${ }^{5}$ The prevalence of LBP in this study was found to be $46.8 \%$. This is similar to the point prevalence of LBP amongst rice farmers in Thailand, a developing country. ${ }^{15} \mathrm{It}$ is also comparable to the prevalence of $46 \%$ in a study amongst staff in a rural hospital in Nigeria, ${ }^{8}$ but it is higher than the point prevalence of $20 \%$ from a study amongst office workers.

The prevalence of LBP in this study was higher amongst men compared with women. In a review by Punnett, the attributable factor for LBP was also higher amongst men (41\%) than women $(32 \%))^{2}$ The reason proffered was that men usually engage in occupations associated with heavy physical workload and whole-body-vibration compared with women. ${ }^{2}$ This higher prevalence in males was corroborated by another group of researchers. ${ }^{7}$ In contrast to the findings in our study, female rice farmers in Thailand were more likely to develop LBP than males. ${ }^{15}$ Another study amongst staff in a rural hospital also found that female workers had a greater prevalence of LBP. ${ }^{8}$

Some authors reported that the risk of developing LBP increases with advancing age and amongst females, however, others studies reported no such association between these factors. ${ }^{16}$ Louw reported in a systematic review that the point prevalence of LBP amongst African adolescents and adults was $12 \%$ and $32 \%$ respectively. ${ }^{5}$ Similarly, Taechasubamorn et al. reported the highest prevalence of LBP amongst young adults aged 25 years to 34 years. ${ }^{15}$ Older people were found to experience the more persistent and severe form of LBP compared with young adults. ${ }^{17}$ A report from Sweden showed that LBP was common amongst elderly Post Office pensioners who had previously engaged in lifting heavy loads for more than 20 years. ${ }^{17}$

In this study, occupational activities and previous back injury were significantly associated with LBP. Thirty-seven percent of back pain worldwide accounts for an estimated 0.8 million disability-adjusted life years (DALY) with resultant work time and economic loss. ${ }^{18}$ Physical efforts, such as manual exertion and exposure to whole-body-vibration are the common physical ergonomics related to LBP. ${ }^{9}$ Some authors found that the majority of those reporting LBP were frequently exposed to 'stressful situations' in their occupation. ${ }^{11}$

The highest proportion of LBP in this study was found amongst respondents who commonly adopted the stooping position during their daily activities. This is comparable to the findings of another Nigerian study that associated LBP with heavy physical work, bending, poor posture and prolonged sitting or standing. ${ }^{8}$ In addition, most rice farmers experienced increased LBP from slouched sitting (56.2\%), forward bending $(70.8 \%)$ and lifting $(83.2 \%) .{ }^{15}$
The majority $(57.3 \%)$ of the respondents using either the firm or orthopedic mattresses had LBP. Our study found no significant association between LBP and the sleeping materials $(p=0.377)$. This result differed from the multicenter trial by Kovacs, where pain and disability amongst patients with chronic, non-specific LBP improved when using the medium firm mattresses. ${ }^{19}$ The firmness of the mattress was rated in their study along the European Committee for Standardization scale, with the firmest mattress rated as 1 and the softest rated as $10 .{ }^{19}$ Self-assessment of the mattress type was carried out by the respondents in this study, which could have affected the results.

Tobacco smoking was significantly associated with LBP amongst the respondents. This was in agreement with previous studies in which the prevalence of LBP was higher amongst current smokers and ex-smokers than in nonsmokers, ${ }^{8}$ as well as the study by Vindigni that reported higher levels of smoking in people with LBP. ${ }^{11}$

For the female respondents in this study, logistic regression analysis showed that a waist circumference of $88 \mathrm{~cm}$ or more $(p=0.005, \mathrm{OR}=1.029, \mathrm{CI}=1.009-1.050)$ was significantly associated with LBP. This is similar to the report in which $71 \%$ of the respondents were found to be either overweight or obese, with $16 \%$ not being physically active and $35.9 \%$ engaging in less than 30 minutes of exercise daily. ${ }^{11}$

Being overweight is more common in women compared with men. Its prevalence increases in mid-life and then decreases over time. Being overweight causes an increase in the pressure on the structures of the lower back and that may lead to lumbar disc herniation and subsequent LBP. Studies reported an association between being overweight and experiencing LBP. ${ }^{7,20}$ Chronic medical illnesses, such as hypertension, diabetes mellitus and obesity with advancing age, have been reported to influence the occurrence of tendon and ligament diseases which can lead to LBP. ${ }^{21}$ For the female respondents, logistic regression analysis showed that dysmenorrhea $(p=0.012, \mathrm{OR}=2.260, \mathrm{CI}=1.197-4.268)$ was associated with LBP. This is similar to the study in which LBP and headaches were found to contribute the most to the severity of dysmenorrhoea. ${ }^{22}$

\section{Conclusion}

Back pain is a common cause of absenteeism at work and functional disability, which has assumed a public health importance. ${ }^{23}$ In Australia, LBP is commonly treated with exercise. ${ }^{11}$ Lifestyle modification, such as regular exercise, smoking cessation and weight reduction, and culturally acceptable health promotion programmes have been found to be beneficial in reducing the disability associated with LBP. ${ }^{5,11}$ Workers at risk of LBP need to modify their postures during occupational activities by preventing excessive flexion and extension movements. ${ }^{2}$ In our setting there is a high prevalence of LBP amongst adult patients, with several modifiable risk factors identified. Various levels of prevention should be employed to alter occupational activities and lifestyle habits. 


\section{Acknowledgements}

We acknowledge the Department of Family Medicine (UCH) and the Head of Physiotherapy Department (UCH) for their support during the study.

\section{Competing interests}

The authors declare that they have no financial or personal relationship(s) that may have inappropriately influenced them in writing this article.

\section{Author contribution}

T.O.A. (University College Hospital) was the project leader. He was involved in the project design and made conceptual contributions. A.M.O. (University College Hospital) and L.A.A. (University College Hospital) were responsible for the project design, collection of data, analysis and writing of the manuscript.

\section{References}

1. Samad N, Abdullah H, Moin S, Tamrin S, Hashim Z. Prevalence of low back pain and its risk factors among school teachers. Am J Appl Sc. 2010;7(5):634-639. http://dx.doi.org/10.3844/ajassp.2010.634.639

2. Punnett $L$, Prüss-Ustün $A$, Nelson $D$, Estimating the global burden of low back pain attributable to combined occupational exposures. Am J Ind Med. 2005;1-14.

3. Tavafian SS, Jamshidi A, Mohammad K, Montazeri A. Low back pain education and short term quality of life: a randomized trial. BMC Musculoskelet Dis. 2007;8:21. http://dx.doi.org/10.1186/1471-2474-8-21, PMid:17328809, PMCid:1808456

4. Waddell G, Burton AK. Occupational health guidelines for the management of low back pain at work: evidence review. Occup Med. 2001;51(2):124-135. http:// dx.doi.org/10.1093/occmed/51.2.124

5. Louw QA, Morris LD, Grimmer-Somers K. The Prevalence of low back pain in Africa: a systematic review. BMC Musculoskelet Dis. 2007:8:105. doi:10.1186/1471 2474-8-105. http://dx.doi.org/10.1186/1471-2474-8-105

6. Guo H-R. Working hours spent on repeated activities and prevalence of back pain Occup Environ Med. 2002;59:680-688. http://dx.doi.org/10.1136/oem.59.10.680, PMCid:1740219

7. Omokhodion FO, Sanya AO. Risk factors for low back pain among office workers in Ibadan, Southwest Nigeria. Occup Med. 2003;53(4):287-289. http://dx.doi. org/10.1093/occmed/kqg063
8. Omokhodion FO, Umar US, Ogunnowo BE. Prevalence of low back pain among staff in a rural hospital in Nigeria. Occup Med. 2000:50(2):107-110. http://dx.doi. org/10.1093/occmed/50.2.107

9. Vandergrift JL, Gold JE, Hanlon A, Punnett L. Physical and psychosocial ergonomic risk factors for low back pain in automobile manufacturing workers. Occup Environ Med. 2012;69(1):29-34. http://dx.doi.org/10.1136/oem.2010.061770

10. Freburger JK, Holmes GM, Agans RP, et al. The rising prevalence of chronic low back pain. Arch Intern Med. 2009;169(3):251-258. http://dx.doi.org/10.1001/ archinternmed.2008.543, PMid:19204216

11. Vindigni D, Walker BF, Jamison JR, Da Costa C, Parkinson L, Blunden S. Low back pain risk factors in a large rural Australian Aboriginal community. An opportunity for managing co-morbidities? Chirop \& Osteopat. 2005;13:21. doi:10.1186/17461340-13-21. http://dx.doi.org/10.1186/1746-1340-13-21

12. National Population Commission of Nigeria. National and states population and housing tables. 2006 population and housing census of the Federal Republic of Nigeria [homepage on the Internet]. 2009 [2011 February 14]. Available from: http://www.population.gov.ng/images/the_elderly.pdf

13. World Health Organization. Expert committee on physical status: the use and interpretation of anthropometry physical status. Technical Report Series no. 854 Geneva: World Health Organization; 1995.

14. Sánchez-García S, García-Peña C, Duque-López MX, Juárez-Cedillo T, CortésNúñez AR, Reyes-Beaman S. Anthropometric measures and nutritional status in a healthy elderly population. BMC Public Health. 2007;7:2. http://dx.doi. org/10.1186/1471-2458-7-2

15. Taechasubamorn P, Nopkesorn T, Pannarunothai S. Prevalence of low back pain among rice farmers in a rural community in Thailand. J Med Assoc Thai. 2011;94(5):616-621. PMid:21675453

16. Nagasu M, Sakai K, Ito A, et al. Prevalence and risk factors for low back pain among professional cooks working in school lunch services. BMC Public Health. 2007;7:171. http://dx.doi.org/10.1186/1471-2458-7-171

17. Plouvier S, Gourmelen J, Chastang J, Lanoë J, Leclerc A. Low back pain around retirement age and physical occupational exposure during working life. BMC Public Health. 2011;11:268. http://dx.doi.org/10.1186/1471-2458-11-268, PMid:21526996, PMCid:3103456

18. Fingerhut M, Driscoll T, Nelson DI, et al. Contribution of occupational risk factors to the global burden of disease - a summary of findings. SJWEH Suppl. 2005;1:58-61.

19. Kovacs FM, Abraira V, Peña A, et al. Effect of firmness of mattress on chronic nonspecific low-back pain: Randomised, double-blind, controlled, multicentre trial. Lancet. 2003;362: 1599-604. http://dx.doi.org/10.1016/S0140-6736(03)14792-7

20. Yip YB, Ho SC, Chan SG. Tall stature, overweight and the prevalence of low back pain in Chinese middle-aged women. Int J Obes. 2001;25(6):887-892. http:// dx.doi.org/10.1038/sj.ijo.0801557, PMid:11439304

21. Mirtz TA, Greene L. Is obesity a risk factor for low back pain? An example of using the evidence to answer a clinical question. Chiropr Osteopat. 2005;13:2. http:// dx.doi.org/10.1186/1746-1340-13-2

22. Tariq N, Hashim MJ, Jaffery $\mathrm{T}$, et al. Impact and health-seeking behavior of premenstrual symptoms and dysmenorrhoea. BJMP. 2009;2(4):40-43.

23. Skargen El, Oberg BE. Predictive factors for 1-year outcome of low-back and neck pain in patients treated in primary care: Comparison between the treatment strategies chiropractic and physiotherapy. Pain. 1998;77:201-207. http://dx.doi. org/10.1016/S0304-3959(98)00101-8 